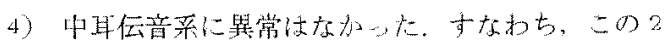

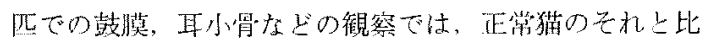
較して们勋差異在見比せなかった。

総括ならびに考按：以」の实験結果より，来す，虹彩

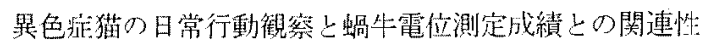

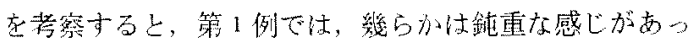

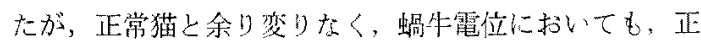

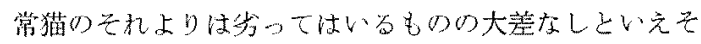
らであった。これに対して，第2例は特に鈍重であり， 蛹牛電位も，正常猫の之机上り極端仁低く，日常行動観 察上冎牛電位测定成績上の閒にはかなり関連性がありそ 5 に思えた。

したがって，次の奏䮖である中耳・内耳の観察では， 少くとも第2 例におい下は，西程度の病的变化名存在 ナるであるらと予想されたが，結果上しては，特別異常 广所見は認以られな加った。

以上のことより，虹彩垬色症猫では，日常行動面なと

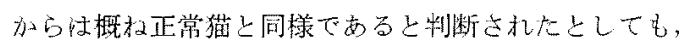
聴賞などの点で，正常猫よりはかなり㸓る(明らかに婹 覚障害がある) ものがあると考えられる，また，平衡觉 に関しても，落下試験では正常と判定されたけれる゙も，

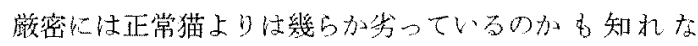
?.

何れにしても，中耳・内耳の観察結果が正常であった

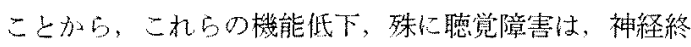
末装置であるユルチ器より中枢側の障青に上るもの上屍 えられる。

ここで、今一度，Waardenburg 症侯群に窘及する
し，本症假群に関しての詳細な報告は，1951年にWaa. rdenburgkよってなされているけ机どす，本症候群に 関する款告は，1900年代の初め頃より数多くなされてい る。しかし，猫などの動物実験では，その障害部位に関 しては洪定的なこしはわかっていない上らに思われ，七

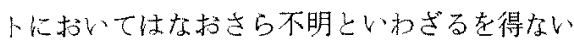

したがって，本症候群の猫（2匹…4 耳) の奉験成 續では，例数が少く，特にヒトの場合の内耳などの病理 所胃が明らかでないため，障害部位や障害程度などに関 しては，推定の城をですき，より貝体的かつ明確な説明は 今後の研究に期待したい.

質問 草杊 潤 (東北大)。形態学的に変化ないから といって内耳に買常がないと言えるかどらか. CMが下 がっているのは何故上考えるか力。応答 折田洋造 明らかな蜦牛電位低下例では，内耳の sruface prepar ation 手技による矮察結果では，その原因に関し具体的 なことはいい難く，現段階では推測の域をでない。

質問 志多 字 (大阪鉄道). 形態学的変化がなくても $\mathrm{CM}$ 感度が低下するようなことはよくあるのた，このデ 一夕老方さり，形態学的変化のないことに引张られ て，内耳在正常であると判断することに問題があるので はないか。応答 折田洋造 まだ例数が少なく、文 献的考察加巨，決定的なことはいえない追加水 越治（京拊医大），色素代謝に関係する生化学的な。 のに䦗題があると琹好る。この種の動物に，種々の負 荷䘮かけることにより，聴觉上具体的な差がでるのでは ないか、今後の発展老期待する。

(B $80-1109-20911$ )

\title{
51. 内耳血流遮断時間と内リンパ電位の回復性に関する検討
}

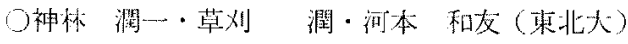

内リン人電位は血管条で生成されており，二の部位は 内耳の中て名特に代謝が活発でその機能在維持寸るため

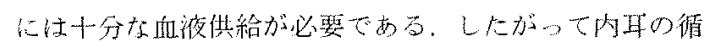

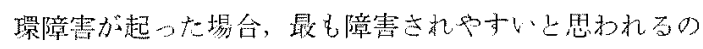
快、この内リンハ電位である。

近年問題七なっている笑発難聴の原因上して内耳の循

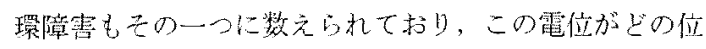
の anoxia にたえら万かについては大変鼠味深い

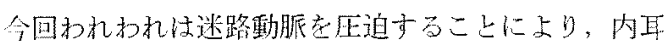

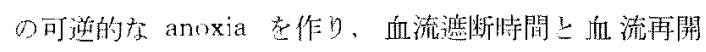

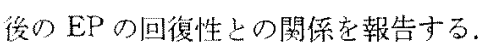

実験方法：プライエル反射正常なるモルモット28匹を

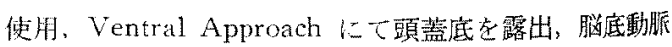
老明らかにした後、正丹空経由で EPを記録し，谜路動

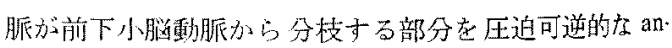

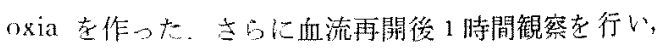
その後 Heart cutにより anoxia 定作った。

実験結果：O10分閒の anoxia では EPは死迫と同時 念激な低下を示し，異電位となりさらに圧迫に解除と 伴に急速な回復在示し，全例才ーバーシュート後，元 
のレベルにまで回復した。

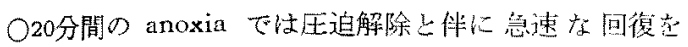
示し、ほぼ元のレベルにまで回復した。

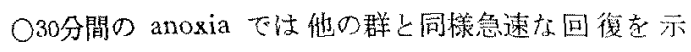
すものが多いが，一旦元のレぶル近くまだ回復した 後, 压迫解除後20３0分には 40〜70 $\mathrm{mV}$ 上なりこの 侹を保った。

○45分間の anoxia ではほぼ 30 分と同様の回復パター ンが認められた。

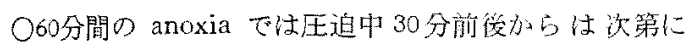

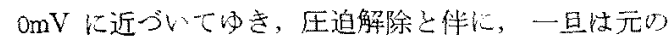
レベルの50〜90\%まで回復するが，徐々に低下し，30 分後には16〜66mV上なりこの值を保った。

O120分間の anoxia 厄゙, 圧迫解除上伴にEP は回復

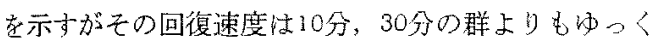
りで苟りまた一旦は元のレベルの30〜80\%まで回復 するが，30分後に忙 $25 \sim 38 \mathrm{mV}$ の做で安定した。

な扩本実娩中，迷路動脈圧迫に上り内正血流㵂断が十分 であることを確称めるため，呼吸器停止に上り asphy. ctic anoxia 在作り変化加ないこ上老確加内た。

Oanoxia 後のEP の回復度をみるため圧迫解除後, 全 群とも1時間にわたり経過を観察した。さらにその時 の $\mathrm{K}^{+}$の Diffusion potential 乞考えら机る真の電位 について調べるため全例 Heart cutに上り anoxia

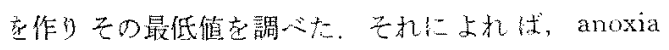

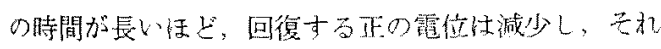
に伴い真の電位も減少寸る。
O30分以上: anoxia にした群で法60分間の血流回復に

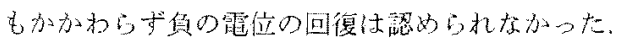
O圧迫解除上りEPが回復後最大做に至るまで红要する

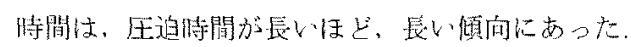

まとめ：以上わこ上より内リン：電位は少标くとも10 〜20分の anoxia から住充回得できる。30年〜60分 の anoxia で怯70 54\%の部分的な回徣が認められた。

さらに120分間の血流遮断にもかかわらず，内りンパ 電位は部分的ではあるが，35\%程度の回復在示した。 Konishi あるい法 Perlman などの報告によ机ば，CM の Rivival time は拉上そ50 60分, AP Rivival time が50分だあるこ上考考える上内りンパ霍位の回復が直接 媤力の回復上いらこ上仕できないにしても，120分間も

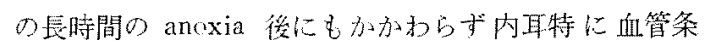
は, その末梢聴觉器ししてり機能を部分的にで蛙るが 回復できるよいう結論に達した。

質問 志多 享 (大阪銑道)。回復した $\mathrm{EP}$ が再び 低下して一定の lower level に stay 码伎何故か. strial vessels $の$ blood flow について観察したか。专

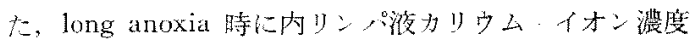
が変化与る上教えるか。応答 神林潤一盘管条の 巾の血流回復状態については観察してない，応管 草刈 潤 Overshoot の原因や血管条の練胞がどの上う に障等されているか子含後の検討要要する問題と思5。 辰時閶の anoxia だ $\mathrm{K}^{+}, \mathrm{Na}^{+}$イオンの組成が変化し 加かな加回復しない上推察している。

(B $80-1110-20020$ )

\section{2. 重心の偏倚乞動摇

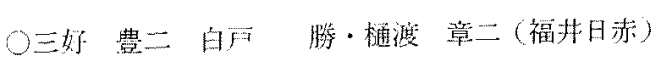

目的：直立位にある人体の平衡小，文特面に対寸る重 心位置の関倸上!，常に何等かの俯倚が生じ，二机に見 合ら立直りにより維持されている，したがって、重心の 面より体平衡在换討寸る時は，重心の摇ぎにはこの雨者 が含まれていることに留意する必要がある。しかも雨者

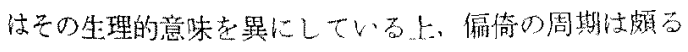
長く,かつ不規則であるのた，この雨者起国時に処理す

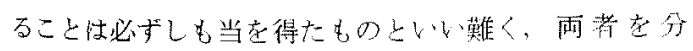
離，検刢す心きものと考えた。

方法：左右，前後の 2 方向に分けて検出した重心動摇 值を、データーレコーダーに収録し、沪波器在用いて，

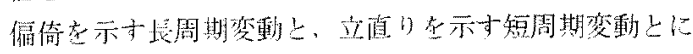

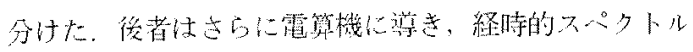
列在求め，全経過を证し、周波数成分がどの上5に変動 して行くか検討した。史す次元同㭙にA/D変撸在行 いかの，512点ずつのデータ定1群として，群ごとに次

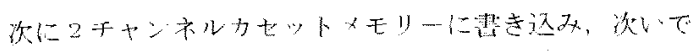
群ご上に高速フーリェ変㨦に上りパワースペクトル在求

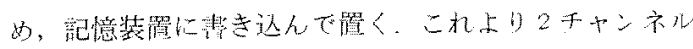
同時にまたは1チャンネルずつ，必要な部分意，グラフ 